\title{
ORGANOLEPTIC, TEXTURAL AND WHIPPING PROPERTIES OF WHIPPED CREAM WITH DIFFERENT STABILIZER BLENDS
}

\author{
Walid Gafour, Esmat Aly $\bowtie$ \\ Food Technology Research Institute, Agricultural Research Center \\ 9 Elgamaa str., 12613 Giza, Egypt
}

\begin{abstract}
Background. Whipped cream is one of the dairy emulsions commonly used as a topping for desserts and cake decorations. Several stabilizers were used to obtain whipped creams of a good quality and with a stable topping. This research study aimed to evaluate the organoleptic, textural, and whipping properties of whipped cream prepared using different stabilizer blends.

Materials and methods. In this study, $0.04 \%$ of different stabilizers, including carboxymethylcellulose (CMC), $\kappa$-carrageenan (KC), or KC blended (in the ratio of 3:1) with cremodan se 30 (C30), 80 (C80) or 216 (C 216), were used in preparing the whipped cream samples. The whipping properties (whipping time, overrun, and foam stability), viscosity, texture, and organoleptic properties were evaluated.

Results. The obtained findings revealed that using a $\mathrm{KC}+\mathrm{C} 80$ blend led to the lowest whipping time (76 s) and the highest overrun (120\%). Also, pronounced changes obtained by using these stabilizers and the more suitable viscosity were obtained by using a $\mathrm{KC}+\mathrm{C} 80$ blend. Moreover, using a $\mathrm{KC}+\mathrm{C} 80$ blend led to higher values of hardness $(4.38 \mathrm{~N})$ and cohesiveness $(0.53)$ and lower values of springiness $(4.65 \mathrm{~mm})$, chewiness $(5.60 \mathrm{~mJ})$, and adhesiveness $(8.66 \mathrm{~mJ})$. The data obtained demonstrated that all whipped the cream samples were organoleptically accepted, and the whipped cream prepared with a $\mathrm{KC}+\mathrm{C} 80$ blend had the highest score of flavor, texture, appearance, and overall acceptability.

Conclusion. It could be concluded that using a $\mathrm{KC}+\mathrm{C} 80$ stabilizer blend improved the whipping and texture properties, viscosity, and organoleptic properties of whipped cream.
\end{abstract}

Keywords: whipped cream, whipping properties, textural properties, stabilizers, carrageenan, cremodan

\section{INTRODUCTION}

Whipped cream and ice cream are considered the most common dairy emulsions. Whipped cream, in particular, has a high fat content (typically $30-40 \%$; Zhao et al., 2009) and is used in desserts, pastries, cakes, and ice creams (Sajedi et al., 2014). Besides its pleasant and acceptable taste, good quality whipped cream is distinguished by its appropriate stability, hardness, and high overrun (OR), which can be enhanced by providing an efficient envelopment of the air bubbles by a partially coalesced milk fat globule membrane (Wang et al., 2019). It could easily be prepared through whipping of unhomogenized dairy cream at $5^{\circ} \mathrm{C}$ for $2-3 \mathrm{~min}$ at a moderately high speed, thus producing a whipped cream characterized by its high overrun (100-120\%), and has a stable topping form "firm peaks". Although whipped cream has a sufficient shelf-life of one day, its main defect is the foam instability which occurs as serum leakage is observed after several hours of processing (Stanley et al., 1996). 
Structurally, whipped cream is a complex emulsion-based foam structure in which partially coalesced fat droplets stabilize air bubbles at the air-water interface. However, several phenomena such as creaming, phase inversion, coalescence, and flocculation can contribute to whipped cream instability (Fredrick et al., 2010). Its stability is of great importance and various studies have been conducted on keeping its stability using various stabilizers (Camacho et al., 2005; Sajedi et al., 2014; Smith et al., 2000; Zhao et al., 2009) and emulsifiers (Pugnaloni et al., 2004).

Normally, stabilizers are used during storage to prevent coalescence and creaming. Many stabilizers have been used, including carrageenans which are sulphated and anionic polysaccharides extracted from red algae (Falshow et al., 2001). This stabilizer is well-known for its interactions with casein micelles (Everett, 2007) and participates in preventing serum leakage thanks to its ability to improve cream viscosity and reduce serum phase separation from the whipped cream air cell network (Stanley et al., 1996). In addition to stabilizers, emulsifiers (proteins or polysaccharides) are often used to enhance whipped cream stability (Zhao et al., 2009). Proteins are usually used to improve the textural properties and stability of whipped cream due to its gelling and surfactant capabilities whereas polysaccharides are typically served to enhance viscosity or to create a gel-like product (de Silva Lannes and Ignácio, 2013). Smith et al. (2000) used an emulsifier-stabilizer system consisting of mono- and diglycerides, disodium phosphate, sodium citrate, guar gum, carrageenan, locust bean gum, and soy lecithin, which can be used for a similar purpose. Manzoor (2017) recently used cremodan as a stabilizing agent in ice cream processing. This type of stabilizer is a combined stabilizer and emulsifier system consisting of mono- and diglycerides, sodium alginate, guar gum, carrageenan and locust bean gum.

Although the importance of using suitable stabilizers and emulsifiers in overcoming whipped cream destabilization, selecting the right stabilizer or emulsifier and its quantity is also of great importance to produce a product with good characteristics. In this context, using the improper type and quantity of stabilizer might participate in increasing the whipping time and reducing the overrun where a high viscosity will greatly affect the whipping properties (Walstra et al., 1999).
Because of the above-mentioned information, the current study was devoted to formulating whipped creams with the addition of various stabilizers (including carboxymethylcellulose, carrageenan, carrageenan blended with three different types of cremodan) and studying its effects on the organoleptic, textural, and whipping properties of the resultant whipped creams.

\section{MATERIALS AND METHODS}

\section{Materials}

Heavy cream ( $40 \%$ fat), and skimmed milk were obtained from The Dairy Technology Unit, Faculty of Agriculture, Cairo University. Stabilizers, including CMC and $\kappa$-carrageenan, were obtained form MIFAD Misr, Egypt, while cremodan se 30, 80, and 216 were obtained from Danisco Denmark. Cane sugar was purchased from a local market at Giza, Egypt.

\section{Processing of whipped cream}

The whipped cream formulations were prepared according to Sajedi et al. (2014) with slight modifications. Briefly, the fat content of the whipped cream samples was standardized to $35 \%$ by adding raw skimmed milk, in which $0.04 \%$ of the stabilizer $\kappa$-carrageenan $(\mathrm{KC})$ with/without cremodan se 30 (C30), $80(\mathrm{C} 80)$ and $216(\mathrm{C} 216)$, at a ratio of 3:1, was dissolved at $70^{\circ} \mathrm{C}$ for $30 \mathrm{~min}$ during intensive stirring (3000 rpm) by a rotor-stator mixer. Skimmed milk with dissolved stabilizer was mixed with tempered cream $\left(70^{\circ} \mathrm{C}\right)$, and cooled in a water bath. Sugar $(8 \%$ w/w) was also added. The samples were then pasteurized at $85^{\circ} \mathrm{C}$ for $5 \mathrm{~min}$ in a water bath. After that, it was homogenized at $50^{\circ} \mathrm{C}$ at $3000 \mathrm{rpm}$ for 1 min using an Ultra Turrax homogenizer (Ultra-Turrax-T18, IKA, Germany). The treated creams were held at $5^{\circ} \mathrm{C}$ for 24 hours to encourage fat crystallization and facilitate the production of the foam structure during whipping. After cooling, these treated creams were ready to be aerated. Firstly, a portion of the whipping cream samples was whipped at different times to reach the maximum overrun using a classic stand mixer system (Girmi, model SB45, Italy). Thereafter, at the optimum time found in the previous step, the rest of each sample was whipped and the resultant products were kept at $5^{\circ} \mathrm{C}$. Thus, the organoleptic, 
textural, and whipping properties of each sample were analyzed. Three replicates were conducted for each sample.

One whipped cream sample prepared with $0.04 \%$ carboxymethylcellulose (CMC), since $\mathrm{CMC}$ is the most commonly used stabilizer in whipped cream and ice cream, was formulated at the same time and called WC-CMC. While the other treatments were provided with the following codes: WC-KC (whipped cream contains $\kappa$-carrageenan), WC-KC+C30 (whipped cream contains $\kappa$-carrageenan + cremodan se 30 ), WC$-\mathrm{KC}+\mathrm{C} 80$ (whipped cream contains $\mathrm{\kappa}$-carrageenan + cremodan se 80 ), and $\mathrm{WC}-\mathrm{KC}+\mathrm{C} 216$ (whipped cream contains $\kappa$-carrageenan + cremodan se 216).

\section{Whipping properties}

Determination of whipping time. Each sample was whipped at $950 \pm 5 \mathrm{rpm}$ using an overhead stirrer (Eurostar power control-visc, IKA Labortechnik, Staufen, Germany) at $6^{\circ} \mathrm{C}$ as described previously (Borjesson et al., 2015). Whipping time was defined as the time needed to achieve maximum torque value, which corresponds to maximum foam firmness before the foam collapses.

Measurement of overrun (OR). Overrun is known as the volume of air entrapped in a certain volume of cream. The same volumes of whipped and unwhipped cream were weighed and overrun was measured according to Fredrick et al. (2013) and calculated as the volume of air in foam related to the volume of cream according to the following equation:

Overrun, OR $\%=[($ weight of unwhipped cream weight of whipped cream) / weight of whipped cream] $\times 100$

Determination of foam stability. Foam stability (also known as serum loss or serum leakage) was calculated using the slightly modified method of Eden et al. (2016). In brief, $55 \mathrm{~g}$ of each sample was transferred to a $1 \mathrm{~mm}$ mesh wire sieve and the collected serum drained at $5^{\circ} \mathrm{C}$ for $24 \mathrm{~h}$ was used to calculate the serum leakage according to the equation of Lim et al. (2008):

Serum leakage, $\%=$ (weight of serum collected $/$ weight of initial whipped cream) $\times 100$

\section{Measurement of apparent viscosity}

The apparent viscosity of whipped cream was measured at $5^{\circ} \mathrm{C}$ using a Brookfield digital rotational viscometer (model DV-II+, Brookfield Engineering Laboratories Inc., Middleboro, MA, USA) using a spindle LV2 at speed of $60 \mathrm{rpm}$. The spindle was allowed to rotate in the sample for $1 \mathrm{~min}$ at $5^{\circ} \mathrm{C}$, at Torque range $(10-100 \%)$. The apparent viscosity reading in centipoises $(\mathrm{cP})$ was recorded. This analysis was carried out 24 hours after production because this time allowed the completion of fat globule crystallization.

\section{Analysis of textural properties}

The texture properties of the whipped creams were measured using three aliquots containing $150 \mathrm{~g}$ of each sample according to Bourne (1978). The hardness, cohesiveness, springiness, chewiness, and adhesiveness of the whipped creams were measured at $6 \pm 2^{\circ} \mathrm{C}$ by a Universal Testing Machine (TMS-Pro) equipped with $(250 \mathrm{lbf})$ a load cell and connected to a computer programmed with Texture ProTM texture analysis software (program, DEV TPA with hold) using a cylinder probe (49.95 $\mathrm{mm}$ diameter). The probe was used to uniaxially compress the samples to $50 \%$ of their original height at a speed of $50 \mathrm{~mm} / \mathrm{s}$, and trigger force $1 \mathrm{~N}$, deformation $50 \%$ and holding $2 \mathrm{~s}$ between cycles. Each sample was subjected to two subsequent cycles (bites) of compression-decompression.

\section{Organoleptic properties}

Ten qualified panelists were employed for the sensory evaluation of the whipped creams. The main parameters evaluated were flavor and taste, body and texture, color and appearance, and overall acceptability, and their rating scale was set as 45, 40, 15, and 100, respectively (El-Abd et al., 2017). The whipped cream samples were maintained at $4^{\circ} \mathrm{C}$ during the sensory evaluation to keep their freshness and integrity.

\section{Statistical analysis}

The obtained data were statistically analyzed with ANOVA to identify the significant differences between the means of the samples. All data were expressed as a mean \pm standard deviation of three replicates. The means of the results were compared by the Tukey test with a confidence interval set at $95 \%$. 


\section{RESULTS AND DISCUSSION}

\section{Whipping properties of whipped cream}

The whipping properties, including the whipping time $(\mathrm{s})$, overrun (\%) and serum leakage (\%) of the whipped cream samples prepared with different stabilizers are shown in Table 1. As can be seen in Table 1, noticeable changes were observed related to the whipping properties (whipping time and overrun) of the whipped cream resulting from using different stabilizers blends. The results displayed that the whipping time ranged between $76-165 \mathrm{~s}$. Use of $\kappa$-carrageenan increased the whipping time to $165 \mathrm{~s}$, while mixing it with cremodan se 30 , 80 , and 216 reduced the whipping time to 147,76 , and $136 \mathrm{~s}$. The lowest value (76 s) of whipping time was for $\mathrm{WC}-\mathrm{KC}+\mathrm{C} 80$ which significantly decreased compared to other treatments. Thus, using cremodan se stabilizers, especially cremodan se 80 , led to a pronounced decrease in whipping time while keeping its high overrun. This variation in whipping time could mainly be attributed to the stabilizer type added to the formulations since the whipped creams were aged for an equal time, pasteurized at equivalent temperatures, and contained equivalent formulations of ingredients. Several substances, including proteins (casein and whey protein),

Table 1. Whipping properties of whipped creams with different stabilizer blends

\begin{tabular}{lccc}
\hline Treatment & $\begin{array}{c}\text { Whipping } \\
\text { time } \\
\mathrm{s}\end{array}$ & $\begin{array}{c}\text { Overrun } \\
\%\end{array}$ & $\begin{array}{c}\text { Serum } \\
\text { leakage } \\
\%\end{array}$ \\
\hline WC-CMC & $140 \pm 10^{\mathrm{a}}$ & $95 \pm 5.00^{\mathrm{a}}$ & 0 \\
WC-KC & $165 \pm 10^{\mathrm{a}}$ & $100 \pm 5.00^{\mathrm{b}}$ & 0 \\
WC-KC+C30 & $147 \pm 10^{\mathrm{a}}$ & $110 \pm 7.00^{\mathrm{ab}}$ & 0 \\
WC-KC+C80 & $76 \pm 4^{\mathrm{b}}$ & $120 \pm 2.50^{\mathrm{b}}$ & 0 \\
$\mathrm{WC}-\mathrm{KC}+\mathrm{C} 216$ & $136 \pm 3^{\mathrm{a}}$ & $105 \pm 6.00^{\mathrm{b}}$ & 0 \\
\hline
\end{tabular}

Values are mean \pm SD of three independent replicates. Means with different superscripts in each column are significantly different $(P<0.05)$. WC-CMC - whipped cream contains carboxymethylecellulose, $\mathrm{WC}-\mathrm{KC}$ - whipped cream contains $\kappa$-carrageenan, $\mathrm{WC}-\mathrm{KC}+\mathrm{C} 30$ - whipped cream contains $\kappa$-carrageenan + cremodan se 30 , WC-KC+C80 - whipped cream contains $\kappa$-carrageenan + cremodan se $80, \mathrm{WC}-\mathrm{KC}+\mathrm{C} 216$ - whipped cream contains $\kappa$-carrageenan + cremodan se 216 . polysaccharides, emulsifiers, and stabilizers (e.g. cremodan, and $\kappa$-carrageenan), act as surfactants that can improve partial coalescence leading to a shorter whipping time. Hotrum et al. (2005) displayed that whey protein isolate-stabilized cream had a shorter whipping time than sodium caseinate-stabilized cream.

Regarding the overrun (OR), its values ranged between $95-120 \%$. The lowest value $(95 \%)$ was for WC-CMC, while the highest value (120\%) was for $\mathrm{WC}-\mathrm{KC}+\mathrm{C} 80$. Thus, OR \% significantly increased when using a $\mathrm{KC}+\mathrm{C} 80$ blend compared to the other treatments. Karazhian and Mahdian (2018) reported that the OR value of ice cream improved when increasing the concentration of the stabilizers used. Previously published data has demonstrated the relationship between some stabilizer blends and emulsion overrun and viscosity. Smith et al. (2000) revealed that the addition of Aertex stabilizer led to lower OR values in whipped creams. This could mainly be explained by the increased serum phase viscosity that resulted in higher shearing resistance, decreased trapped air during whipping, and eventually a longer whipping time.

Serum leakage is another feature of the whipping properties that has great importance on an industrial and commercial scale and represents an indicator of whipped cream stability. The data presented in Table 1 revealed that serum loss was 0 for all treatments at $5^{\circ} \mathrm{C}$ for up to one day. This means that the prepared whipped creams have a higher stability and can keep their shape for a long time in refrigerated conditions. Thus, it can easily be marketed, especially as a topping for desserts and cake decorations. Similar serum leakage has been reported by El-Abd et al. (2017) in whipped creams incorporated with whey protein concentrate (WPC), $\beta$-lactoglobulin ( $\beta$-LG), and alfa-lactalbumin $(\alpha-\mathrm{LA})$. Thus, stabilizers and proteins, as surfactants, might behave similarly when added to whipped creams.

\section{Apparent viscosity of whipped cream}

Figure 1 summarizes the apparent viscosity values of various whipped creams prepared with different stabilizer blends. These findings indicate that viscosity values ranged between $38-142 \mathrm{cP}$. The highest viscosity value $(142 \mathrm{cP})$ was for whipped cream prepared using $0.04 \% \kappa$-carrageenan (WC-KC) followed by that containing a blend of $\kappa$-carrageenan and cremodan 


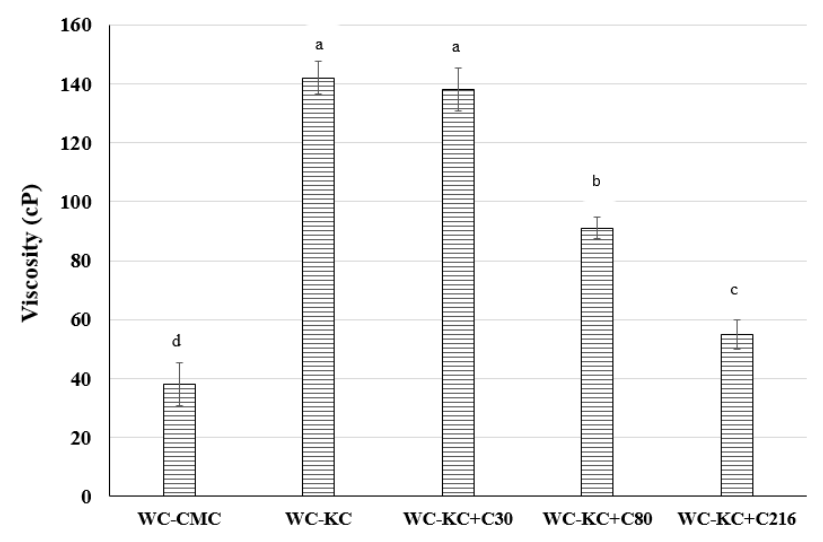

Fig. 1. Apparent viscosity (cP) of whipped creams with different stabilizer blends. Values are mean \pm SD of three independent replicates. Column chart with different letters are significantly different $(p<0.05)$. WC-CMC - whipped cream contains carboxymethylcellulose, WC-KC - whipped cream contains $\kappa$-carrageenan, WC-KC+C30 - whipped cream contains $\kappa$-carrageenan + cremodan se $30, \mathrm{WC}-\mathrm{KC}+\mathrm{C} 80-$ whipped cream contains $\kappa$-carrageenan + cremodan se 80 , $\mathrm{WC}-\mathrm{KC}+\mathrm{C} 216$ - whipped cream contains $\kappa$-carrageenan + cremodan se 216

se 30, 80, 216 (WC-KC+C30, WC-KC+C 80 , and $\mathrm{WC}-\mathrm{KC}+\mathrm{C} 216$, respectively). The lowest value was reported for WC-CMC. This characteristic is very complicated and it is affected by various factors including concentration, temperature, and the physical state of the dispersed phase (Kristensen et al., 1997). Furthermore, shear rate is another factor affecting the apparent viscosity and it has been found that increasing the shear rate results in lower apparent viscosity by deforming the interaction between droplets and causing disruption, thus reducing the apparent viscosity (Peamprasart and Chiewchan, 2006). Likewise, the addition of stabilizers and emulsifiers is one of the most important factors influencing the apparent viscosity of whipped cream. Because these substances improve the adsorption of partly coalesced fat at the air interface by reducing the interface tension (Paquin and Dickinson, 1991) and thus can increase serum phase viscosity. In this sense, carrageenan can interact with casein micelles forming a complex of glycomacropeptide that would allow cohesion between membranes and the serum to add overall structural integrity to the foam. To improve the whipping properties, viscosity, and stability of whipped cream, several stabilizers, including locust bean gum and $\kappa$-carrageenan (Camacho et al., 2005), sodium caseinate, whey proteins, hydroxypropyl methylcellulose, xanthan gum (Zhao et al., 2009) and Aertex cream stabilizer (Smith et al., 2000) were used. For getting whipped creams with desirable properties, it is of great importance to use the proper type and quantity of stabilizer. These results are supported by several previous studies (Camacho et al., 2005; Kováčová et al., 2010).

\section{Texture properties of whipped cream}

The texture is defined as the sensory and functional manifestation of the structural, mechanical, and surface properties of foods that the senses of sight (visual texture), sound (auditory texture), touch (tactile texture), and kinesthetics can perceive (Szczesniak, 2002). The texture properties of various foods were tested extensively using instrumental TPA (Ninan et al., 2011). Thus, texture analysis is a standard quality control method in the food industry, but interestingly, it has not been commonly used in studies of whipped cream microstructure (Nguyen et al., 2015). TPA involves applying a controlled force to the product and monitoring its response over time (Burey et al., 2009). Simulated oral mastication conditions are applied to various foods in this analysis resulting in TPA forcetime curves being obtained. During TPA analysis, the various parameters, including hardness, cohesiveness, springiness, chewiness, and adhesiveness, can be evaluated. These parameters are of great importance for processing properties and food quality (Chandra and Shamasundar, 2015).

As can be seen in Table 2, significant changes $(p<0.05)$ were observed in TPA attributes (including hardness, cohesiveness, springiness, chewiness, and adhesiveness) of the whipped cream samples prepared with different stabilizers. The treatment of $\mathrm{WC}-\mathrm{KC}+\mathrm{C} 80$ had the highest hardness value of $4.38 \mathrm{~N}$ $(p<0.05)$ followed by WC-KC+C216, WC-KC, WC-CMC and WC-KC+C30 samples, which had values of $3.97,3.55,3.38$, and $3.24 \mathrm{~N}$, respectively. Hardness is correlated with the strength of the product structure under compression and is the highest force during the first step of compression. It demonstrated the maximum force needed to compress food between the molar teeth (Szczesniak, 2002).

Besides hardness, cohesiveness (consistency) refers to the strength of internal bonds that make up 
Gafour, W., Aly, E. (2020). Organoleptic, textural and whipping properties of whipped cream with different stabilizer blends. Acta Sci. Pol. Technol. Aliment., 19(4), 425-433. http://dx.doi.org/10.17306/J.AFS.2020.0784

Table 2. Texture profile analysis of whipped creams with different stabilizers

\begin{tabular}{lllccc}
\hline \multicolumn{1}{c}{ Treatment } & $\begin{array}{c}\text { Hardness } \\
\mathrm{N}\end{array}$ & $\begin{array}{c}\text { Springiness } \\
\mathrm{mm}\end{array}$ & $\begin{array}{c}\text { Cohesiveness } \\
\text { ratio }\end{array}$ & $\begin{array}{c}\text { Chewiness } \\
\mathrm{mJ}\end{array}$ & \multicolumn{2}{c}{$\begin{array}{c}\text { Adhesiveness } \\
\mathrm{mJ}\end{array}$} \\
\hline $\mathrm{WC}-\mathrm{CMC}$ & $3.38 \pm 0.03^{\mathrm{d}}$ & $5.85 \pm 0.05^{\mathrm{a}}$ & $0.49 \pm 0.01^{\mathrm{c}}$ & $9.65 \pm 0.05^{\mathrm{a}}$ & $11.12 \pm 0.01^{\mathrm{a}}$ \\
$\mathrm{WC}-\mathrm{KC}$ & $3.55 \pm 0.05^{\mathrm{c}}$ & $5.20 \pm 0.10^{\mathrm{c}}$ & $0.47 \pm 0.01^{\mathrm{d}}$ & $8.70 \pm 0.10^{\mathrm{bc}}$ & $9.34 \pm 0.04^{\mathrm{b}}$ \\
$\mathrm{WC}-\mathrm{KC}+\mathrm{C} 30$ & $3.24 \pm 0.05^{\mathrm{e}}$ & $5.38 \pm 0.08^{\mathrm{b}}$ & $0.49 \pm 0.01^{\mathrm{d}}$ & $9.12 \pm 0.02^{\mathrm{b}}$ & $8.94 \pm 0.10^{\mathrm{c}}$ \\
$\mathrm{WC}-\mathrm{KC}+\mathrm{C} 80$ & $4.38 \pm 0.07^{\mathrm{a}}$ & $4.65 \pm 0.05^{\mathrm{d}}$ & $0.53 \pm 0.01^{\mathrm{a}}$ & $5.60 \pm 0.44^{\mathrm{d}}$ & $8.66 \pm 0.08^{\mathrm{d}}$ \\
$\mathrm{WC}-\mathrm{KC}+\mathrm{C} 216$ & $3.97 \pm 0.12^{\mathrm{b}}$ & $4.75 \pm 0.05^{\mathrm{d}}$ & $0.51 \pm 0.01^{\mathrm{b}}$ & $8.37 \pm 0.46^{\mathrm{c}}$ & $8.99 \pm 0.10^{\mathrm{c}}$ \\
\hline
\end{tabular}

Values are mean $\pm \mathrm{SD}$ of three independent replicates. Means with different superscripts in each column are significantly different $(P<0.05)$. WC-CMC - whipped cream contains carboxymethylcellulose, WC-KC - whipped cream contains $\kappa$-carrageenan, WC$-\mathrm{KC}+\mathrm{C} 30$ - whipped cream contains $\kappa$-carrageenan + cremodan se $30, \mathrm{WC}-\mathrm{KC}+\mathrm{C} 80$ - whipped cream contains $\kappa$-carrageenan + cremodan se 80 , WC-KC+C216 - whipped cream contains $\kappa$-carrageenan + cremodan se 216.

the body of food and the degree to which a food can be deformed before it ruptures (Radocaj et al., 2011). The cohesiveness values of the whipped cream samples were in the range of 0.47 to 0.53 . The highest value obtained was for whipped cream prepared with $\kappa$-carrageenan and cremodan se $80(\mathrm{WC}-\mathrm{KC}+\mathrm{C} 80$ ) and the lowest value obtained was for whipped cream containing only $\kappa$-carrageenan (WC-KC). Cohesiveness is known as the ratio of the positive force area during the second compression to that of the first compression. It can be measured as the rate at which the material is disintegrated under mechanical action. So, it reflects the product's ability to hold together. In the same context, El-Abd et al. (2017) reported that the hardness and cohesiveness of whipped cream samples increased due to the addition of whey proteins. Moreover, Peng et al. (2018) recently found that using milk fat globule membrane protein, which may be used as an emulsifier and stabilizer, led to the hardness and consistency of the whipped cream samples increasing as compared to the control whipped cream.

The springiness values of the five whipped cream samples are given in Table 2. The sample of WC-CMC showed the highest springiness value (5.85) compared to the other whipped cream samples. Springiness is a textural parameter which is related to sample elasticity. Springiness in TPA is related to the height that the food recovers during the time that elapses between the end of the first bite and the start of the second bite. If the springiness is high, more energy in the mouth is required for mastication (Rahman and
Al-Mahrouqi, 2009). Interestingly, a lower springiness value of 4.65 was obtained from whipped cream with $\kappa$-carrageenan blended with cremodan se $80(\mathrm{WC}-\mathrm{KC}+\mathrm{C} 80)$.

The chewiness values of the whipped cream samples are presented in Table 2. Chewiness is a measure of the energy needed to chew the food and is generally reported for solid foods. The chewiness values of the various whipped cream samples varied from 5.60 to $9.65 \mathrm{~mJ}$. The chewiness is most difficult to measure precisely because it requires compressing, shearing, piercing, grinding, tearing, and cutting along with adequate saliva lubrication at body temperatures (Bhale, 2004).

Regarding adhesiveness, it is an important characteristic of whipped cream and represents the flow capability or liquid state of materials (Chandra and Shamasundar, 2015). It is known as the area of negative force for the first bite and is the work needed to overcome the attractive forces between the food surface and the surface of other materials with which the food comes into contact (Kasapis, 2009). According to Table 2, the maximum adhesiveness value $(11.12 \mathrm{~mJ})$ was obtained for the WC-CMC sample, whereas the minimum adhesiveness value $(8.66 \mathrm{~mJ})$ was obtained for $\mathrm{WC}-\mathrm{KC}+\mathrm{C} 80$. The higher adhesiveness value means a soft texture (Chandra and Shamasundar, 2015).

Camachoetal.(2005)demonstrated that the emulsion structure is more greatly influenced by $\lambda$-carrageenan than by locust bean gum, although the latter seems to participate in the structure's shear stability as it influences the viscosity after shear. As $\kappa$-carrageenan, 
Gafour, W., Aly, E. (2020). Organoleptic, textural and whipping properties of whipped cream with different stabilizer blends. Acta Sci. Pol. Technol. Aliment., 19(4), 425-433. http://dx.doi.org/10.17306/J.AFS.2020.0784

Table 3. Sensory evaluation of whipped cream with different stabilizer blends

\begin{tabular}{lcccc}
\hline \multicolumn{1}{c}{ Treatment } & Flavor and taste (45) & Body and texture (40) & Color and appearance (15) & Overall acceptability (100) \\
\hline WC-CMC & $43 \pm 0.5^{\mathrm{a}}$ & $38 \pm 0.50^{\mathrm{ab}}$ & $10 \pm 0.50^{\mathrm{a}}$ & $91 \pm 0.50^{\mathrm{b}}$ \\
WC-KC & $42 \pm 1^{\mathrm{a}}$ & $38 \pm 1^{\mathrm{bc}}$ & $10 \pm 1^{\mathrm{a}}$ & $90 \pm 0.5^{\mathrm{b}}$ \\
WC-KC+C30 & $42 \pm 0.5^{\mathrm{a}}$ & $35 \pm 1.50^{\mathrm{c}}$ & $10 \pm 1.00^{\mathrm{a}}$ & $87 \pm 2.50^{\mathrm{b}}$ \\
WC-KC+C80 & $44 \pm 1.00^{\mathrm{a}}$ & $40 \pm 0.00^{\mathrm{a}}$ & $11 \pm 0.50^{\mathrm{a}}$ & $98 \pm 1.00^{\mathrm{a}}$ \\
WC-KC+C216 & $43 \pm 1.00^{\mathrm{a}}$ & $38 \pm 0.50^{\mathrm{ab}}$ & $11 \pm 0.50^{\mathrm{a}}$ & $92 \pm 1.00^{\mathrm{b}}$ \\
\hline
\end{tabular}

Values are mean $\pm \mathrm{SD}$ of three independent replicates. Means with different superscripts in each column are significantly different $(P<0.05)$. WC-CMC - whipped cream contains carboxymethylcellulose, WC-KC - whipped cream contains $\kappa$-carrageenan, WC$-\mathrm{KC}+\mathrm{C} 30$ - whipped cream contains $\kappa$-carrageenan + cremodan se $30, \mathrm{WC}-\mathrm{KC}+\mathrm{C} 80$ - whipped cream contains $\kappa$-carrageenan + cremodan se 80 , WC-KC+C216 - whipped cream contains $\kappa$-carrageenan + cremodan se 216

the great influence of $\lambda$-carrageenan may probably be attributed to its interactions with milk proteins. Complexes of casein micelles with $\lambda$-carrageenan have been documented, promoting weak gelling in the emulsion (Camacho et al., 2005).

\section{Organoleptic properties of whipped cream}

Results of the organoleptic attributes of the whipped cream samples are given in Table 3. These results display that all samples are sensorially acceptable with the overall acceptability ranging between $87-98$. In general, the addition of $\kappa$-carrageenan with/without cremodan se did not lead to significant changes in flavor or appearance but led to significant changes in texture when compared to the whipped cream prepared with CMC (WC-CMC). The whipped cream containing $\kappa$-carrageenan (WC-KC) and cremodan se 80 (WC$-\mathrm{KC}+\mathrm{C} 80)$ acquired the highest values of flavor and taste (44), body and texture (40), color and appearance (11) and overall acceptability (98) followed by the whipped creams containing a stabilizer blend of $\kappa$-carrageenan and cremodan se 216 (WC-KC+C216). Inclusion of cremodan se 80 and 216 stabilizers and emulsifier system as part of the blends led to the sensory attributes of the obtained whipped creams increasing, whereas cremodan se 30 led to a slight decrease in the overall acceptability (87) when compared to the samples of WC-CMC (91) and WC-KC (90). Several authors have confirmed the relationship between physical properties and sensory evaluation in the dairy emulsion system including ice cream and whipped cream. BahramParvar and Tehrani (2011) displayed that most sensory attributes of ice cream are related to rheological properties in some way. In the same sense, the findings of some studies have exhibited that viscosity and sensory properties are correlated (BahramParvar et al., 2010). This correlation was supported by the findings obtained by Bahram-Parvar et al. (2013), which reported that the use of $\kappa$-carrageenan in ice cream formulations decreased the values of instrumental hardness and improved the smoothness of the samples. Like ice cream, the physical properties of whipped cream are highly influenced by the presence of hydrocolloid stabilizers and their type, composition of blends and applied amount are the most important factors involved. Thus, these factors greatly influence the different properties of whipped cream.

\section{CONCLUSION}

Stabilizer blends containing $\kappa$-carrageenan and cremodan se $80(\mathrm{KC}+\mathrm{C} 80)$ at a ratio of $3: 1$ seems to improve the whipping properties where the whipped cream prepared with this stabilizer blend had the lowest whipping time and the highest overrun. Moreover, moderate apparent viscosity was obtained by using this stabilizer blend. From the texture profile analysis conducted on these whipped creams, suitable and good texture parameters were obtained for the whipped cream $(\mathrm{WC}-\mathrm{KC}+\mathrm{C} 80)$ prepared with this stabilizer blend. Additionally, these data display the relationship between texture properties and sensory acceptability and thus support previously reported findings of this correlation. 


\section{REFERENCES}

BahamParvar, M., Razavi, S. M., Tehrani, M. M., Alipour, A. (2013). Optimization of functional properties of three stabilizers and $\kappa$-carrageenan in ice cream and study of their synergism. J. Agr. Sci. Technol., 15(4), 757-769.

BahramParvar, M., Tehrani, M. M. (2011). Application and functions of stabilizers in ice cream. Food Rev. Int., 27, 389-407.

BahramParvar, M., Razavi, S. M., Khodaparast, M. H. (2010). Rheological characterization and sensory evaluation of typical soft ice cream made with selected food hydrocolloids. Food Sci. Technol. Int., 16(1), 79-88.

Bhale, S. D. (2004). Effect of ohmic heating on color, rehydration and textural characteristics of fresh carrot cubes. Master's Dissertation. Baton Rouge: Louisiana State University and Agricultural and Mechanical College.

Borjesson, J., Dejmek, P., Lofgren, R., Paulsson, M., Glantz, M. (2015). The influence of serum phase on the whipping time of unhomogenised cream. Int. Dairy J., 49, 56-61.

Bourne, M. (1978). Texture profile analysis. Food Technol., $32,62-66$.

Burey, P., Bhandari, B. R., Rutgers, R. P. G., Halley, P. J., Torley, P. J. (2009). Confectionery gels: A review on formulation, rheological and structural aspects. Int. J. Food Prop., 12, 176-210.

Camacho, M. M., Martinez-Navarrete, N., Chiralt, A. (2005). Rheological characterization of experimental dairy creams formulated with locust bean gum (LBG) and א-carrageenan combinations. Int. Dairy J., 15, 243-248.

Chandra, M. V., Shamasundar, B. A. (2015). Texture profile analysis and functional properties of gelatin from the skin of three species of freshwater fish. Int. J. Food Prop., 18(3), 572-584.

da Silva Lannes, S. C., Ignácio, R. M. (2013). Structuring fat foods. In I. Muzzalupo (Ed.), Food industry (pp. 6591). IntechOpen.

Eden, J., Dejmek, P., Löfgren, R., Paulsson, M., Glantz, M. (2016). Native milk fat globule size and its influence on whipping properties. Int. Dairy J., 61, 176-181.

El-Abd, M. M., Salama, F. M., Zeidan, M. A., Baker, E. A. (2017). Functional properties of whipped cream as affected by addition of $\beta$-lactoglobulin and $\alpha$-lactalbumin. J. Food Dairy Sci., 8(9), 387-390.

Everett, D. W. (2007). Cream products. In Y. H. Hui (Ed.), Handbook of food products manufacturing (pp. 725749). John Wiley.

Falshow, R., Bixler, H. J., Johndro, K. (2001). Structure and performance of commercial kappa-2 carrageenan extract: I. Structure analysis. Food Hydrocoll., 15 (4-6), 441-452.

Fredrick, E., Walstra, P., Dewettinck, K. (2010). Factors governing partial coalescence in oil-in-water emulsions. Adv. Colloid Interfac. Sci., 153, 30-42.

Fredrick, E., Heyman, B., Moens, K., Fischer, S., Verwijlen, T., Moldenaers, P., ..., Dewettincka, K. (2013). Monoacylglycerols in dairy recombined cream: II. The effect on partial coalescence and whipping properties. Food Res. Int., 51, 936e945.

Hotrum, N. E., Cohen Stuart, M. A., van Vliet, T., van Aken, G. A. (2005). Proposing a relationship between the spreading coefficient and the whipping time of cream. In E. Dickinson (Ed.), Food colloids: Interactions, microstructure and processing (pp. 317-325). Cambridge, UK: Royal Society of Chemistry.

Karazhian, R., Mahdian, E. (2018). Effects of fat replacers and stabilizers on rheological, physicochemical and sensory properties of reduced-fat ice cream. J. Agr. Sci. Technol., 15, 1163-1174.

Kasapis, S. (2009). Developing minced fish products of improved eating quality: An interplay of instrumental and sensory texture. Int. J. Food Prop., 12, 11-26.

Kováčová, R., Štětina, J., Čurda, L. (2010). Influence of processing and $\kappa$-carrageenan on properties of whipping cream. J. Food Eng., 99(4), 471-478.

Kristensen, D., Jensen, P. Y., Madsen, F., Birdi, K. S. (1997). Rheology and surface tension of selected processed dairy fluids: influence of temperature. Dairy Sci., 80, 2282-2290.

Lim, S.-Y., Swanson, B. G., Clark, S. (2008). High hydrostatic pressure modification of whey protein concentrate for improved functional properties. J. Dairy Sci., 91, 1299-1307.

Manzoor, M. F. (2017). Quality evaluation of soy milk ice cream prepared with ipomoea batatas starch and meteroxylon sagu powder as stabilizing agent. Int. J. Agr. Life Sci. - IJALS, 3(1), 157-163.

Nguyen, V., Duong, C. T., Vu, V. (2015). Effect of thermal treatment on physical properties and stability of whipping and whipped cream. J. Food Eng., 163, 32-36.

Ninan, G., Zynudheen, A. A., Joseph, J. (2011). Physicochemical and texture properties of gelatin and water gel desserts prepared from the skin of freshwater carps. Fish Technol., 48, 67-74.

Paquin, P., Dickinson, E. (1991). Emulsion and foam: interactions of proteins/lipids at interface. Proc. $23^{\text {rd }}$ International Dairy Congress, Montreal, Quebec, Canada. Int. Dairy Federation, Brussels, Belgium. 
Peamprasart, T., Chiewchan, N. (2006). Effect of fat content and preheat treatment on the apparent viscosity of coconut milk after homogenization. J. Food Eng., 77, 653-658.

Peng, F., He, S., Yi, H., Li, Q., Xu, W., Wang, R., Ma, Y. (2018). Physical, textural, and rheological properties of whipped cream affected by milk fat globule membrane protein. Int. J. Food Prop., 21(1), 1190-1202.

Pugnaloni, L. A., Dickinson, E., Ettelaie, R., Mackie, A. R., Wilde, P. J. (2004). Competitive adsorption of proteins and low-molecular-weight surfactants: Computer simulation and microscopic imaging. Adv. Colloid Interfac. Sci., 107, 27-49.

Radocaj, O. F., Dimic, E. B., Vujasinovic, V. B. (2011). Optimization of the texture of fat-based spread containing hull-less pumpkin (Cucurbita pepo L.) seed press-cake. Acta Period. Technol., 42, 131-143.

Rahman, M. S., Al-Mahrouqi, A. I. (2009). Instrumental texture profile analysis of gelatin gel extracted from grouper skin and commercial (bovine and porcine) gelatin gels. Int. J. Food Sci. Nutr., 60, 229-242.

Sajedi, M., Nasirpour, A., Keramat, J., Desobry, S. (2014). Effect of modified whey protein concentrate on physical properties and stability of whipped cream. Food Hydrocoll., 36, 93-101.

Smith, A. K., Goff, H. D., Kakuda, Y. (2000). Microstructure and rheological properties of whipped cream as affected by heat treatment and addition of stabilizer. Int. Dairy J., 10(4), 295-301.

Stanley, D. W., Goff, H. D., Smith, A. K. (1996). Texture-structure relationships in foamed dairy emulsions. Food Res. Int., 29, 1-13.

Szczesniak, A. S. (2002). Texture is sensory property. Food Qual. Prefer., 13, 215-225.

Walstra, P., Geurts, T. J., Noomen, A., Jellema, A., Van Boekel, M. A. J. S. (1999). Dairy technology: principles of milk properties and processes. New York: Marcel Dekker.

Wang, Y., Yuan, D., Li, Y., Li, M., Wang, Y., Li, Y., Zhang, L. (2019). Thermodynamic and whipping properties of milk fat in whipped cream: a study based on DSC and TD-NMR. Int. Dairy J., 97, 149-157.

Zhao, Q., Zhao, M., Yang, B., Cui, C. (2009). Effect of xanthan gum on the physical properties and textural characteristics of whipped cream. Food Chem., 116, 624-628. 